\title{
Prevalensi Kecacingan dan Hubungan Dengan PHBS Pada Anak Sekolah di Wilayah Kerja Puskesmas Ranomut Kota Manado
}

\author{
Indra Elisabet Lalangpuling 1 \\ ${ }^{1}$ Jurusan Teknologi Laboratorium Medis, Poltekkes Kemenkes Manado, Indonesia
}

\begin{tabular}{l}
\hline \hline Article Info \\
\hline Article history: \\
Received Dec $12^{\text {th }}, 2019$ \\
Revised Jan $23^{\text {th }}, 2020$ \\
Accepted Jan $24^{\text {th }}, 2020$ \\
\hline
\end{tabular}

Keyword:

Worm Infection,

Clean and Healthy Behavior, Ranomut Community Health Center

\begin{abstract}
Infection by worms is experienced by many children because of the pattern of worm transmission through food contaminated with worm eggs and transmission through the soil where children tend not to behave clean and healthy life. Worm infections are often neglected because they are classified as chronic diseases so that worm infections are classified as a neglected tropical disease group (Neglected Tropical Disease). Worm infections in children can cause growth disorders and decrease learning achievement. Worm infections can be avoided by improving life behavior related to good environmental hygiene and sanitation. One of the Puskesmas work programs is to collaborate with the School Health Effort (UKS) to improve health services, health education and foster a healthy school environment for school residents. The purpose of this study was to determine the prevalence of helminth infections and their relationship to the Clean and Healthy Behavior of students in the working area of the Ranomut Health Center in Manado. This study is a cross-sectional study of 117 students in sixteen elementary schools. The method ofexamining stool samples is the native method. The results of the examination showed that 5 students (4\%) hadworm species Ascaris lumbricoides as many as 4 students (3.4\%) and 1 student (0.6\%) had infection Hookworm. Worm infections were found in four schools located near the Ranomut Community Health Center.analysis Chi-square to see the relationship between the incidence of helminth infections and Clean and Healthy Behavior (PHBS) shows there is a relationship between the incidence of helminth infections with the habit of washing hands after defecation (BAB) with a p value. 0.02. The habit of using footwear when playing, washing hands before eating, playing with dirt, the location ofbowel movements, sucking fingers and washing raw food did not show a significant relationship with the incidence of worm infections. Health centers should further improve health services to students through the UKS and counseling programs about helminthiasis to the community especially to parents of students.
\end{abstract}

Copyright $@$ Jurnal Analis Medika Bio Sains All rights reserved.

\section{ABSTRAK}

Infeksi oleh cacing banyak dialami oleh anak-anak karena pola transmisi cacing melalui makanan yang terkontaminasi telur cacing dan transmisi melalui tanah dimana anak-anak cenderung tidak berperilaku hidup bersih dan sehat. Infeksi cacing sering diabaikan karena tergolong penyakit kronis sehingga infeksi cacing digolongkan dalam golongan penyakit tropis yang diabaikan (Negletted Tropical Disease). Infeksi cacing pada anak-anak dapat menyebabkan gangguan pertumbuhan dan menurunkan prestasi belajar. Infeksi cacing dapat dihindari dengan cara memperbaiki perilaku hidup yang berhubungan dengan hygiene dan sanitasi 
lingkungan yang baik. Salah satu program kerja Puskesmas adalah bekerjasama dengan Usaha Kesehatan Sekolah (UKS) untuk meningkatkan pelayanan kesehatan, pendidikan kesehatan dan pembinaan lingkungan sekolah sehat bagi warga sekolah. Tujuan dari penelitian ini adalah untuk mengetahui prevalensi infeksi cacing dan hubungannya dengan Perilaku Hidup Bersih dan Sehat sis wa di wilayah kerja Puskesmas Ranomut Kota Manado. Penelitian ini merupakan penelitian cross-sectional pada 117 siswa di enam belas Sekolah Dasar. Metode Pemeriksaan sampel tinja adalah dengan metode native. Hasil pemeriksaan menunjukkan 5 orang siswa (4\%) mengalami infeksi cacing spesies Ascaris lumbricoides sebanyak 4 orang siswa (3,4\%) dan 1 orang siswa $(0,6 \%)$ mengalami infeksi Hookworm. Kejadian infeksi cacing ditemukan di emapt sekolah yang lokasinya berdekatan dengan Puskesmas Ranomut. Analisis chy-square untuk melihat hubungan antara kejadian infeksi cacing dan Perilaku Hidup Bersih dan Sehat (PHBS) menunjukkan ada hubungan antara kejadian infeksi cacing dengan kebiasaan memcuci tangan setelah Buang Air Besar (BAB) dengan nilai p. 0,02. Kebiasaan menggunakan alas kaki saat bermain, mencuci tangan sebelum makan, bermain tanah, lokasi $\mathrm{BAB}$, menghisap jari dan mencuci bahan makanan mentah tidak menunjukkan hubungan signifikan sengan kejadian infeksi cacing. Puskesmas harus lebih meningkatkan pelayanan kesehatan kepada siswa melalui UKS dan program penyuluhan tentang kecacingan kepada masyarakat khususnya kepada orang tua siswa.

Kata Kunci : Infeksi cacing, Perilaku Hidup Bersih dan Sehat, Puskesmas Ranomut

Copyright $\odot$ Jurnal Analis Medika Bio Sains

\section{Pendahuluan}

Penyakit kecacingan digolongkan dalam kelompok penyakit yang disebut Negleted Tropical Disease (NTD) yaitu penyakit yang diabaikan karena tidak berdampak secara langsung. Prevalensi cacingan di Indonesia secara umum disebabkan oleh dua hal yaitu Iklim dan pola hidup. Iklim tropis dengan suhu, kelembapan dan curah hujan yang tinggi merupakan kondisi yang baik bagi perkembangan telur cacing. Perubahan pada kondisi iklim akan mempengaruhi perubahan pada perkembangan parasit. Pengetahuan dan pola hidup masyarakat yang masih jauh dari kebiasaan hidup sehat, fasilitas sanitasi yang belum memadai, kebisaan tidak memakai alas kaki dan sarung tangan saat bekerja setra kurangnya perhatian tentang kebersihan diri. (Fox et al., 2015)

Infeksi kecacingan dapat dialami oleh semua golongan umur, namun prevalensi inseden pada anakanak lebih tinggi dibandingkan dengan orang dewasa. Anak-anak adalah tahap perkembangan yang cukup rentan terhadap berbagai serangan penyakit karena daya tahan tubuh. Infeksi cacing dapat menimbulkan berbagai penyakit lainnya diantaranya diare, anemia kekurangan gizi dan gangguan pertumbuhan. Infeksi cacingan erat kaitannya dengan pola hidup dan sanitas i. (Setyowatiningsih et al., 2017).

Data dari World Health Organisation (WHO) yang dikutip dari "SUARA.Com" menunjukkan dua puluh empat persen $(24 \%)$ atau 1,5 miliar penduduk dunia saat ini mengalami kecacingan. Kementerian kesehatan melalui bidang Pengendalian Penyakit dan Penehatan Lingkungan (P2PL) menunjunjukkan kasus keca cingan di Indonesia mencapai $28,12 \%$, dimana jumlah ini lebih dari prevalensi rata-rata dunia. Namun beberapa daerah di Indonesia menunjukkan prevalensi diatas lima puluh persen (50\%). Berdasarkan infodatin 2017 tentang kualitas kesehatan masyarakat di provinsi Sulawesi Utara menunjukkan persentasi Desa/Kelurahan yang melaksanakan sanitasi total berbasis masyarakat hanya 15,99\% dari rata-rata Indonesia 47,48\%. Persentasi tempat-tempat umum yang memenuhi syarat kesehatan yaitu 51,49\%, nilai ini masih dibawah dari persentasi rata-rata Indonesia 54,01\%. Persentasi tempat pengolahan makanan yang memenuhi syarat kesehatan hanya $16,24 \%$ dari rata-rata Indonesia 18,04\%. Persentasi rumah tangga kumuh menurut provinsi, menunjukkan 
Sulawesi Utara 8,34 \%, data ini diatas nilai rata-rata Indonesia 6,07\%. Studi pendahuluan yang dilakukan di SDN 54 Kota manado menunjukkan 30\% dari 30 siswa menderita infeksi cacing usus.

\section{Metode Penelitian}

Jenis penelitian menggunakan rancangan cross-sectional untuk mengetahui prevalensi dan sebaran kejadian infeksi cacing pada siswa sekolah dasar di wilayah kerja Puskesmas Ranomut Kota Manado dan menganalisis hubungan antara kejadian infeksi cacing dengan Perilaku Hidup Bersih dan Sehat (PHBS). Lokasi penelitian dilakukan di Sekolah Dasar di wilayah Puskesmas Ranomuut sebanyak 16 SD dan Laboratorium Parasitologi Jurusan Analis Kesehatan Poltekkes Kemenkes Manado. Penelitian dilaksanakan pada bulan Juni sampai Oktober 2019. Sampel dalam penelitian ini adalah siswa kelas empat (4) sebanyak 304 orang dan yang mengumpulkan sampel untuk dilakukan pemeriksaan sejumlah 117 orang yang memenuhi kriteria tidak mengkonsumsi obat cacing dalam 3 bulan terakhir dan lokasi tinggal di sekitar sekolah.

Data siswa diperoleh dari pihak Sekolah Dasar di wilayah Puskesmas Ranomuut dan dikoordinasikan dengan petugas gizi Puskesmas. Penelitian diawali dengan pengisian kuesioner tentang perilaku hidup siswa dan pembagian wadah sampel. Selanjutnya sampel dikumpulkan dan diperiksa dengan metode native. Selanjutnya data dianalisis secara deskriptif dan dilakukan uji chy-square untuk melihat hubungan kejadian infeksi cacing dengan PHBS siswa. Dibuatkan juga peta sebaran kejadian infeksi cacing pada sekolah dasar di wilayah kerja Puskesmas Ranomut Kota Manado.

\section{Hasil Penelitian dan Pembahasan}

Pelaksanaan penelitian diawali dengan koordinasi kepada pihak Puskesmas Ranomut untuk mendistribusikan surat kepada sekolah-sekolah yang menjadi sasaran pengumpulan sampel di wilayah kerja Puskesmas Ranomut yang tesebar di wilayah Dendengan Dalam, Dendengan Luar, Kairagi, Paal 2, dan Perkamil. Pengambilan sampel dilakukan selama satu bulan di enam belas sekolah dasar. Prosedur pengumpulan sampel disosialisasikan kepada siswa kemudian dibagikan wadah sampel. Siswa diminta untuk mengisi kuesioner yang berisi tentang perilaku hidup yang berhubungan dengan infeksi kecacingan. Penjemputan sampel dilakukan selama tiga hari berturut-turut setelah wadah sampel dibagikan dengan memberikan reward berupa snack sehat bagi sis wa yang mengumpulkan sampel.

Banyaknya siswa yang memerima wadah sampel sejumlah 303 orang namun jumlah sampel yang dikembalikan oleh siswa tidak sama dengan wadah sampel yang dibagikan. Selain itu, ada beberapa sampel yang tidak dapat diperiksa karena tidak memenuhi kriteria. Sampel yang dikumpulkan diperiksa di laboratorium Parasitologi Jurusan Teknologi Laboratorium Medis. Kuesioner dan hasil pemeriksaan disajikan dalam bentuk tabel dan dilakukan pemetaan distribusi infeksi kecacingan. 
ISSN: 2656-2456 (Online)

ISSN: 2356-4075 (Print)

Tabel 1. Karakteristik Responden Anak Sekolah Dasar di Wilayah Kerja Puskesmas Ranomut Tahun 2019

\begin{tabular}{|c|c|c|c|}
\hline Variabel & $\mathrm{N}(\%)$ & Variabel & $\mathrm{N}(\%)$ \\
\hline Jenis Kelamin & & Lokasi BAB & \\
\hline Laki-laki & $57(49)$ & Jamban & $109(93)$ \\
\hline Perempuan & $60(51)$ & Luar jamban & $8(7)$ \\
\hline \multicolumn{2}{|c|}{ Kebiasaan menggunaan Alas Kaki } & \multicolumn{2}{|l|}{ Mencuci tangan setelah BAB } \\
\hline Ya & $62(53)$ & $\mathrm{Ya}$ & $101(86)$ \\
\hline Tidak & $55(47)$ & Tidak & $16(14)$ \\
\hline \multicolumn{2}{|c|}{ Mencuci tangan sebelum makan } & \multicolumn{2}{|l|}{ Kebiasaan Menghisap Jari } \\
\hline $\mathrm{Ya}$ & $95(81)$ & $\mathrm{Ya}$ & $19(16)$ \\
\hline Tidak & 22 (19) & Tidak & $98(84)$ \\
\hline \multicolumn{2}{|c|}{ Kebiasaan bermain tanah } & \multicolumn{2}{|l|}{ Mencuci Makanan Mentah } \\
\hline $\mathrm{Ya}$ & $44(38)$ & $\mathrm{Ya}$ & $105(90)$ \\
\hline Tidak & $73(62)$ & Tidak & $12(10)$ \\
\hline
\end{tabular}

Tabel 1 menunjukkan karakteristik responden yang terlibat dalam penelitian. Responden berjumlah 117 murid yang terdiri dari 57 orang siswa (47\%) dan 60 orang siswi (51\%) dengan rentang usia $8-10$ tahun. Pengisian kuesioner tentang kebiasaan keseharian menunjukkan 62 orang (53\%) memiliki kebiasaan menggunakan alas kaki dan 55 orang (47\%) tidak memiliki kebiasaan menggunakan alas kaki saat bermain. Mencuci tangan sebelum makan menjadi kebiasaan bagi 95 orang siswa (81\%) dan 22 orang (19\%) tidak memiliki kebiasaan mencuci tangan sebelum makan. Dalam keseharian, bermain tanah masih menjadi kebiasaan 44 orang siswa (38\%) dan 73 orang (62\%) tidak memiliki kebiasaan bermain tanah. Sejumlah 8 orang siswa (7\%) masih memiliki kebiasaan untuk buang air besar di luar jamban dan 109 siswa (93\%) sudah buang air besar di dalam jamban. Kebiasaan mencuci tangan setelah buang air besar dilakukan oleh 101 orang siswa (86\%) dan sejumlah 16 orang (14\%) masih memiliki kebiasaan tidak mencuci tangan setelah buang air besar. Sebanyak 19 orang siswa (16\%) masih memiliki kebiasaan menghisap jari sedangkan sebanyak 98 orang siswa (84\%) tidak memiliki kebiasaan menghisap jari. Mencuci bahan mentah sebelum dikonsumsi merupakan kebiasaan dari sebagian besar responden yaitu 105 orang siswa (90\%) dan 12 orang siswa (10\%) masih memiliki kebiasaan tidak mencuci bahan makanan mentah sebelum dikonsumsi.

Hasil pemeriksaan sampel yang terkumpul dengan metode native menunjukkan $4 \%$ (5 orang siswa) positif terinfeksi nematoda usus seperti yang ditunjukkan oleh tabel 3. Jenis cacing yang menginfeksi adalah Ascaris lumbricoides $(3,4 \%)$ dan Hookworm $(0,6 \%)$.

Tabel 2. Hasil pemeriksaan Infeksi Nematoda Usus Anak Sekolah Dasar di Wilayah Kerja Puskesmas Ranomut Tahun 2019

\begin{tabular}{ccc}
\hline Hasil Pemeriksaan & $\mathrm{N}$ & $\%$ \\
\hline Positif & 5 & 4 \\
Negatif & 112 & 96 \\
Total & $\mathbf{1 1 7}$ & $\mathbf{1 0 0}$ \\
\hline
\end{tabular}


Jumlah infeksi ini lebih rendah dari penelitian pendahuluan yang dilakukan di salah satu sekolah yang menjadi lokasi penelitian yaitu SDN 54 Manado sebesar 30\%.

Sebaran kejadian infeksi cacing usus sebelum pelaksanaan program POPM ini terlihat pada Gambar 12. Dimana sekolah-sekolah yang teridentifikasi siswanya mengalami infeksi cacing usus berada di sekitar wilayah Puskesmas Ranomut. Hal ini perlu menjadi perhatian bagi pihak puskesma untuk memaksimalkan kegiatan Usaha Kesehatan Sekolah (UKS) dalam bentuk penyuluhan untuk meningkatkan kesadaran siswa tentang bahaya infeksi cacing usus dan bagaimana cara mencegah terjadinya infeksi cacing usus. Selain itu, pelaksanaan dan pemantauan program POPM harus menjadi perhatian.

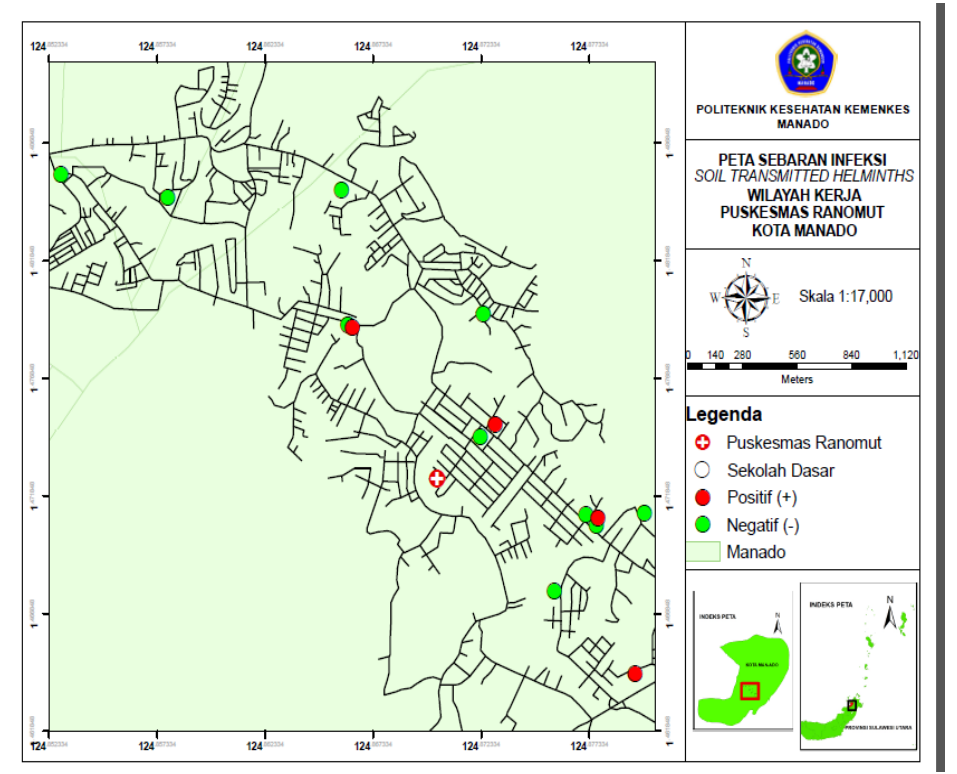

Gambar 1. Peta Sebaran Infeksi Cacing Usus Pada Anak Sekolah Dasar di Wilayah Kerja Puskesmas Ranomut Tahun 2019

Selain itu, penyuluhan perlu juga dilakukan kepada orang tua siswa tentang Perilaku Hidup Bersih dan Sehat (PHBS) karena keluarga berperan besar dalam pengasuhan anak-anak. Penerapan PHBS dalam keluarga dapat mempengaruhi kejadian penyakit yang diderita anggota keluarga. Penelitian yang dilakuakan oleh Hadi (2017) menunjukkan ada hubungan yang signifikan antara penerapan Perilaku Hidup Bersih dan Sehat dengan kejadian penyakit diare di Pondok Pesantren Tremes, Kabupaten Pacitan. (Hadi, 2017)

Dalam penelitian yang dilakukan, responden diminta untuk mengisi kuesioner yang berisikan informasi tentan bagaimana Perilaku Hidup Bersih dan Sehat yang diterapkan oleh responden dalam kesehariannya dan analis is data diuji dengan analisis chi-square untuk menilai hubungan antara kejadian infeksi cacing dengan penerapan Perilaku Hidup Bersih dan Sehat. Tabel 3 menunjukkan nilai p > 0,05 mengartikan tidak ada hubungan yang signifikan antara infeksi cacing dengan kebiasaan menggunakan alas kaki saat bermain dengan 
Tabel 3. Hasil Analisis Hubungan Antara Infeksi Cacing Dengan PHBS Pada Anak Sekolah Dasar di Wilayah Kerja Puskesmas Ranomut Tahun 2019

\begin{tabular}{|c|c|c|c|c|c|c|c|c|c|}
\hline \multirow{2}{*}{\multicolumn{2}{|c|}{ Perilaku }} & \multicolumn{4}{|c|}{ Hasil Pemeriksaan } & \multirow{2}{*}{\multicolumn{2}{|c|}{ Total }} & \multirow{3}{*}{ OR } & \multirow{3}{*}{$p$ value } \\
\hline & & \multicolumn{2}{|c|}{ Positif } & \multicolumn{2}{|c|}{ Negatif } & & & & \\
\hline & & $\mathrm{n}$ & $\%$ & $\mathrm{n}$ & $\%$ & $\mathrm{n}$ & $\%$ & & \\
\hline \multirow{3}{*}{$\begin{array}{l}\text { Menggunakan Alas } \\
\text { Kaki }\end{array}$} & $\mathrm{Ya}$ & 3 & 2,6 & 59 & 50,4 & 52 & 53 & \multirow{3}{*}{1,347} & \multirow{3}{*}{0,748} \\
\hline & Tidak & 2 & 1,7 & 53 & 47,3 & 55 & 47 & & \\
\hline & TOTAL & 5 & 4,3 & 112 & 95,7 & 117 & 100 & & \\
\hline \multirow{3}{*}{$\begin{array}{l}\text { Mencuci Tangan } \\
\text { Sebelum Makan }\end{array}$} & Ya & 3 & 2,6 & 92 & 78,6 & 93 & 81,2 & \multirow{3}{*}{0,326} & \multirow{3}{*}{0,215} \\
\hline & Tidak & 2 & 1,7 & 20 & 17,1 & 22 & 18,8 & & \\
\hline & TOTAL & & & & & & & & \\
\hline \multirow{3}{*}{$\begin{array}{c}\text { Kebiasaan Bermain } \\
\text { Tanah }\end{array}$} & Ya & 3 & 2,6 & 42 & 35,9 & 44 & 37,6 & \multirow{3}{*}{1,111} & \multirow{3}{*}{0,910} \\
\hline & Tidak & 2 & 1,7 & 70 & 59,8 & 73 & 62,4 & & \\
\hline & TOTAL & 5 & 4,3 & 112 & 95,7 & 117 & 100 & & \\
\hline \multirow{3}{*}{ Lokasi BAB } & Jamban & 5 & 4,3 & 104 & 88,9 & 109 & 93,2 & \multirow{3}{*}{0,954} & \multirow{3}{*}{0,536} \\
\hline & Luar Jamban & 0 & 0 & 8 & 6,8 & 8 & 6,8 & & \\
\hline & TOTAL & 5 & 4,3 & 112 & 95,7 & 117 & 100 & & \\
\hline \multirow{3}{*}{$\begin{array}{l}\text { Mencuci Tangan } \\
\text { Setelah BAB }\end{array}$} & Ya & 2 & 1,7 & 99 & 84,6 & 101 & 86,3 & \multirow{3}{*}{0,088} & \multirow{3}{*}{$0,02 *$} \\
\hline & Tidak & 3 & 2,6 & 13 & 11,1 & 16 & 13,7 & & \\
\hline & TOTAL & 5 & 4,3 & 112 & 95,7 & 117 & 100 & & \\
\hline \multirow{3}{*}{ Menghisap Jari } & Ya & 1 & 0,9 & 18 & 15,4 & 19 & 16,2 & \multirow{3}{*}{1,306} & \multirow{3}{*}{0,816} \\
\hline & Tidak & 4 & 3,4 & 94 & 80,3 & 98 & 83,8 & & \\
\hline & TOTAL & 5 & 4,3 & 112 & 95,7 & 117 & 100 & & \\
\hline \multirow{3}{*}{$\begin{array}{l}\text { Mencuci Bahan } \\
\text { Makanan Mentah }\end{array}$} & $\mathrm{Ya}$ & 5 & 4,3 & 100 & 85,5 & 105 & 89,7 & \multirow{3}{*}{0,952} & \multirow{3}{*}{0,440} \\
\hline & Tidak & 0 & 0 & 12 & 10,3 & 12 & 10,3 & & \\
\hline & TOTAL & 5 & 4,3 & 112 & 95,7 & 117 & 100 & & \\
\hline
\end{tabular}

* Signifikan

Menggunakan alas kaki merupakan salah satu cara untuk mencegah penularan infeksi cacing usus khususnya infeksi Hookworm. Pada tanah pasir yang gembur, yang bercampur humus dan terlindung dari matahari langsung, telur cacing tambang menetas menjadi larva rabditiform suhu optimum kemudian berkembang menjadi bentuk filariform yang infektif. Larva filariform dapat berthan $7-8$ minggu di tanah dan harus menembus kulit manusia untuk meneruskan lingkaran hidupnya. Larva menembus kapiler darah dan ikut dalam sirkulasi menuju jantung kanan. Selanjutnya bermigrasi ke paru-paru, menembus bronkus dan menuju ke trakea, terus ke laring dan masuk ke usus halus. Cacing berkembang menjadi dewasa dan dapat mengasilkan $9000-10.000$ telur setiap hari.

Mencuci tangan sebelum makan merupakan perilaku yang harus dibiasakan untuk dilakukan khususnya bagi anak-anak karena pada umumnya anak-anak belum memahami tentang kebersihan dan tidak menerapkan perilaku tersebut dalam keseharian. Tidak memcuci tangan sebelum makan dapat meningkatkan 
resiko infeksi cacing. Telur cacing dapat menempel pada tangan dan mengkontaminasi makanan. Penelitian yang dilakukan oleh Kartini et all (2017) menunjukkan ada hubungan antara kebiasaan mencuci tangan dengan kecacingan. Tabel 3 menunjukkan tidak ada hubungan signifikan antara infeksi cacing dengan kebiasaan mencuci tangan dimana nilai $\mathrm{p}>0,05$.

Usia anak-anak adalah usia dimana dapat bermain dengan bebas tanpa mengkhawatirkan tentang bahaya penyakit yang dapat ditimbulkan. Salah satu kebiasaan yang masih dapat ditemukan pada anak-anak adalah kebiasaan bermain tanah. Kebiasaan ini merupakan faktor pendukung terjadinya infeksi cacing karena beberapa jenis cacing merupakan golongan Soil Transmitted Helminths yaitu golongan cacing yang membutuhkan tanah untuk menjadi infektif dan dapat menjadi sumber penularan bagi manusia. Tabel 3 menunjukkan tidak ada hubungan antara infeksi cacing dengan kebiasaan bermain tanah pada responden, menunjukkan nilai $\mathrm{p}>0,05$.

Tinja yang mengandung telur cacing dapat menjadi sumber penularan bagi orang lain jika orang yang terinfeksi tidak buang air besar di jamban. Telur cacing dapat menjadi infektif di tanah untuk menjadi sumber penularan bagi orang yang tidak menggunakan alas kaki. Jika orang yang terinfeksi buang air besar di sungai, dapat mencemari air sungai, dan menjadi sumber penularan bagi orang yang memanfaatkan air sungai bag $\mathrm{i}$ kebutuhan sehari-hari. Tabel 3 menunjukkan tidak ada hubungan antara lokasi BAB responden dengan infeksi cacing dengan nilai $\mathrm{p}>0,05$.

Mencuci tangan setelah BAB memiliki hubungan yang signifikan dengan infeksi cacing yang dialami responden. Tabel 3 menunjukkan nilai $\mathrm{p}<0,05$. Tangan yang tidak dicuci setelah BAB dapat menjadi sumber penularan infeksi cacing bagi orang lain dan auto infeksi bagi penderita. Kejadian auto infeksi semakin besar kemungkinannya jika anak memiliki kebiasaan menghisap jari. Terdapat 16,2\% responden memiliki kebiasaan menghisap jari, tetapi tidak ada hubungan antara infeksi cacing dengan kebiasaan menghisap jadi yang ditunjukkan pada Tabel 3 dengan nilai $\mathrm{p}>0,05$.

Infeksi cacing dapat ditularkan melalui makanan yang tidak dicuci dengan baik sebelum dikonsumsi seperti buah dan sayur. Karena telur cacing dapat mengkontaminasi buah dan sayuran, terutama bagi tanaman yang menggunakan pupuk kompos. Adrianto (2017) mengungkapkan bahwa beberapa telur cacing juga mengkontaminasi sayuran. Tabel 10 menunjukkan sebagian besar responden $(89,7 \%)$ memiliki kebiasaan mencuci bahan makanan mentah sebelum dimakan, dan nilai $\mathrm{p}>0,05$ menunjukkan tidak ada hubungan antara kejadian infeksi cacing dengan kebiasaan mencuci makanan mentah sebelum dimakan.

\section{Kesimpulan}

Kesimpulan dari penelitian ini adalh sejumlah lima orang siswa (4\%) mengalami infeksi kecacingan dengan spesies Ascaris lumbicoides sebanyak 4 orang siswa (3,4\%) dan Hookworm sebanyak 1 orang siswa $(0,6 \%)$ yang tersebar di 4 Sekolah Dasar yang lokasinya berdekatan dengan Puskesmas Ranomut Kota Manado dan terdapat hubungan antara kebiasaan mencuci tangan setelah BAB dengan infeksi kecacingan pada anak SD di wilayah kerja Puskesmas Ranomut. 
Daftar Pustaka

Adrianto H. Kontaminasi Telur Cacing Pada Sayur dan Upaya Pencegahannya. BALABA. 2017; 13(2):105-14.

Bethony, J., Brooker, S., Albonico, M., Geiger, S. M., Loukas, A., Diemert, D., et al. Soil-transmitted helminth infections: ascarias is, trichuriasis, and hookworm. Lancet. 2006; 367(9521):1521-1532

Chadijah, S., Anastasia, H., Widjaja, J \& Nurjana, M. A. Kejadian penyakit cacing usus di Kota Palu dan Kabupaten Donggala, Sulawesi Tengah. Jurnal Epidemiologi dan Penyakit Bersumber Binatang . 2013; 4(4):181-7.

Fox, N. J., Marion, G., Davidson, R. S., White, P. C. L \& Hutchings, M. R.Climate-driven tipping-points could lead to sudden, high-intensity parasite outbreaks. R. Soc. 2015. Open sci, 2 : 140296. Avalaible at : http://dx.doi.org/10.1098/rsos.140296

Hadi M.I. Hubungan Perilaku Hidup Bersih dan Sehat (PHBS) Terhadap Angka Kejadian Diare Akut Pada Santri Pondok Tremas Kabupaten Pacitan [Skripsi]. Surakarta: Muhammadyah; 2017

https://www.suara.com/health/2017/10/17/174307/duh-24-persen-populasi-dunia-idap-infeksi-cacingan, diakses tanggal 14 Desember 2018

Kamila A. D., Margawati A., Nuryanto. Hubungan Kecacingan Dengan Status Gizi dan Prestasi Belajar Pada Anak Sekolah Dasar Kelas IV dan V di Kelurahan Bandarharjo Semarang. Journal of Nutrition College. 2018; 7 (2):77-83.

Kartini S., Kurniati I., Jayati N.S \& Sumitra W. Faktor-Faktor Yang Berhubungan Dengan Kejadian Kecacingan Soil Transmitted Helminths Pada Anak Usia 1-5 Tahun di Rw 07 Geringging Kecamatan Rumbai Pesisir. JOPSI. 2017; I(Des): 33-9.

Kementerian Kesehatan R I, 2017 . Pusat Data dan Informasi Kemnterian Kesehatan R I

Setyowatiningsih L dan Surati S. Hubungan Higiene Sanitasi dengan Kejadian Infeksi Soil Trnasmitted Helminths pada Pemulung di TPS Jatibarang . Jurnal Riset Kesehatan. 2017; 6(1):40-4. 